\title{
Assessment of pesticide residues and trace element contamination in market gardens of Togo
}

\author{
Madjouma Kanda ${ }^{1}$, Gbandi Djaneye-Boundjou ${ }^{2}$, Kpérkouma Wala ${ }^{1}, K$ issao Gnandi ${ }^{3}$, \\ Komlan Batawila ${ }^{1}$, Ambaliou Sanni ${ }^{4}$ and Koffi Akpagana ${ }^{1 *}$ \\ ${ }^{1}$ Laboratory of Botany and Plant Ecology, Faculty of Science, University of Lomé, Togo. \\ ${ }^{2}$ Laboratory of Water Chemistry, Faculty of Science, University of Lomé, Togo. \\ ${ }^{3}$ Laboratory of Waste Management and Treatment, Faculty of Science, University of Lomé, Togo. \\ ${ }^{4}$ Laboratory of Biochemistry and Molecular Biology, Faculty of Science and Technology, \\ University of Abomey-Calavi, Cotonou, Republic of Benin.
}

Accepted 21 August, 2012

\begin{abstract}
All intensive agriculture, like periurban agriculture, uses massive inputs such as agrochemicals. This study aims to assess the environmental impacts of agrochemical use in periurban agriculture in Togo. It was based on the chemical analyses of soil, water and vegetable samples. These analyses were carried out by gas chromatography on extracts from soil, water and vegetable samples. In soil samples, the concentrations of pesticide residues are lower than $20 \mu \mathrm{g} / \mathrm{kg}$ of dry material. For water samples, contamination levels vary from 0.02 to $1.1 \mu \mathrm{g} / \mathrm{L}$ of dry material with the highest levels for metalaxyl M $(1.1 \mu \mathrm{g} / \mathrm{L})$ and for dimethoate $(1 \mu \mathrm{g} / \mathrm{L})$. In vegetables, the concentrations measured are between 0.01 and $0.1 \mathrm{mg} / \mathrm{kg}$ of dry material. All these concentrations are affected by a positive factor of the maximum limits of residues. These agrochemicals, coupled with periurban environmental management led to the high concentrations of trace elements. Lead and cadmium concentrations in water are 10 and 21 times respectively higher than the maximum concentration allowable for drinking water by the WHO. The study showed that inappropriate use of agrochemicals in Togolese periurban agriculture creates ecological disturbances that could affect produce quality.
\end{abstract}

Key words: Togo, periurban agriculture, agrochemicals, pesticide residues, trace element.

\section{INTRODUCTION}

Periurban agriculture has known very rapid growth in West Africa since Independence and allows meeting the supply of urban centres with fresh vegetables (Delamarche, 2007; Mougeot, 2005; Bouzid et al., 2005; Pélissier, 2000). It is also a catalyst for job creation and generates substantial income for different stakeholders. Nevertheless it uses many inputs (such as agrochemicals) that can have negative effects on the environment and the quality of the product as noted by Delamarche (2007), Koc et al. (2006), Dièye (2006), Bouzid et al. (2005), Midmore and Jansen (2003), Agunwamba (2001), Bahri (2001) and Gerstl (2001).

In Togo, studies carried out to the present only deal

* Corresponding author. E-mail: koffi2100@gmail.com. Tel: +228 90125234. Fax: +228 22219585. with agricultural production and its commercial implications (Kanda, 2003; Talaki, 2002; Schilter, 1991a, b). These studies have also tackled the use of pesticides, substances which have become indispensable to most agricultural practices, without assessing their environmental implications.

This study aims to deepen knowledge on the eventual drawbacks of the use of agrochemicals in the gardening agriculture in Togo on the environment and the quality of vegetable products.

\section{MATERIALS AND METHODS}

Research on pesticide residues

Vegetable, soil and water sampling

Vegetable, soil and water samples were taken in market garden 

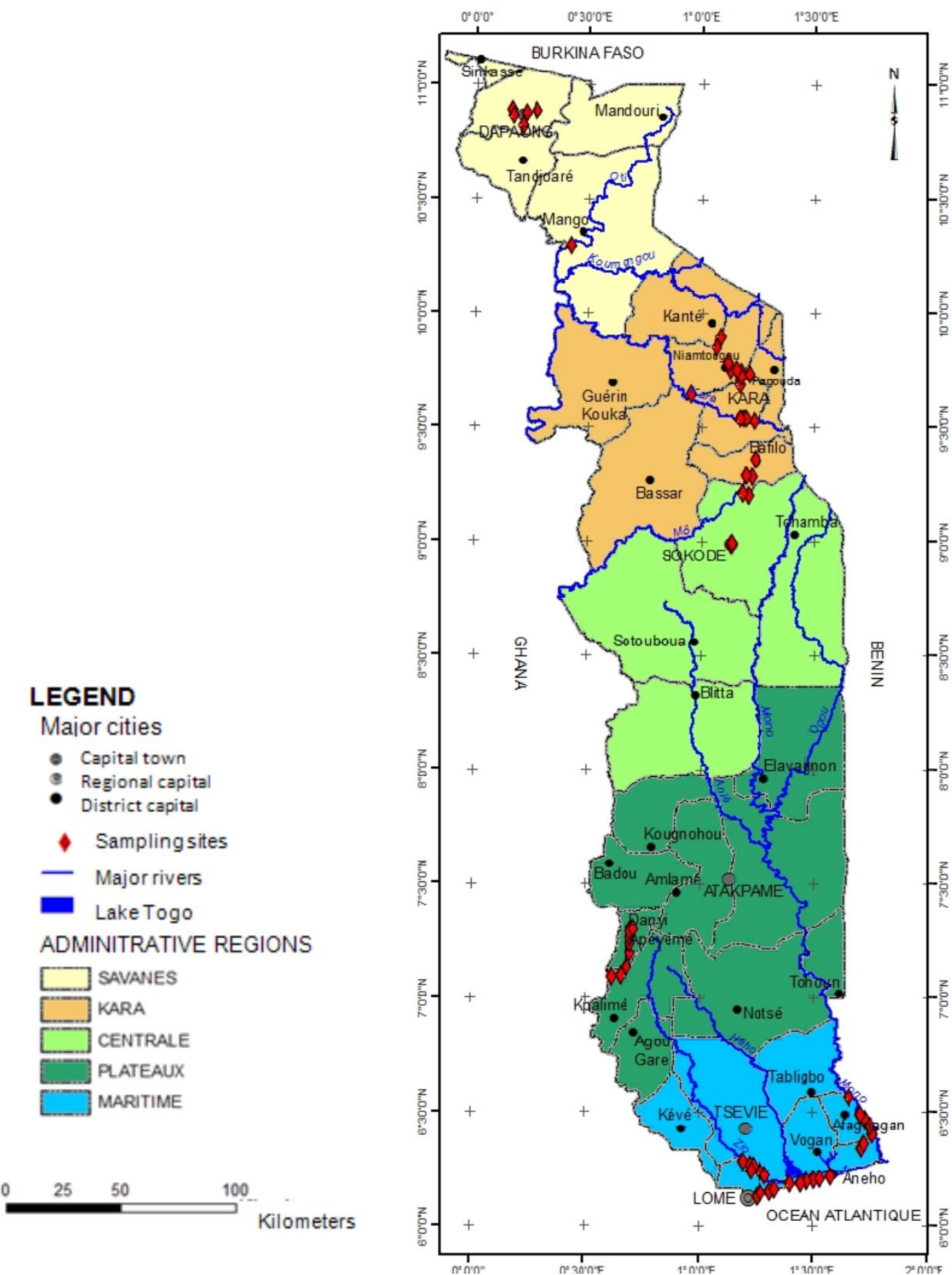

Figure 1. Sample sites in the country (red lozenges).

fields all over the country (Figure 1). In the field, a sample site measuring $20 \mathrm{~cm} \times 20 \mathrm{~cm}$ (Figure 2) was individualised (Savadogo et al., 2006) and its geographic coordinates taken by a GPS ${ }^{\mathrm{TM}}$. Only edible parts of vegetables that are available all year round and were ready for market were sampled (Table 1). For every species, samples were taken at five (5) random points in the square areas and mixed to constitute a composite $1 \mathrm{~kg}$ sample. The samples were washed with tap water and packed in aluminium paper prior to treatment with purified petroleum ether. They were then labelled and conserved in a refrigerator.

In each square, elementary soil samples were taken between a 0 and $20 \mathrm{~cm}$ depth and mixed to constitute a composite sample of 2 $\mathrm{kg}$ each. The samples were dried at 25 to $30^{\circ} \mathrm{C}$ and sieved. $250 \mathrm{~g}$ of the fine fraction (under $2 \mathrm{~mm}$ ) were conserved away from light for later analysis. One litre of water was sampled using washed and decontaminated amber glass bottles (Keith, 1990; Saliot et al., 1992). 


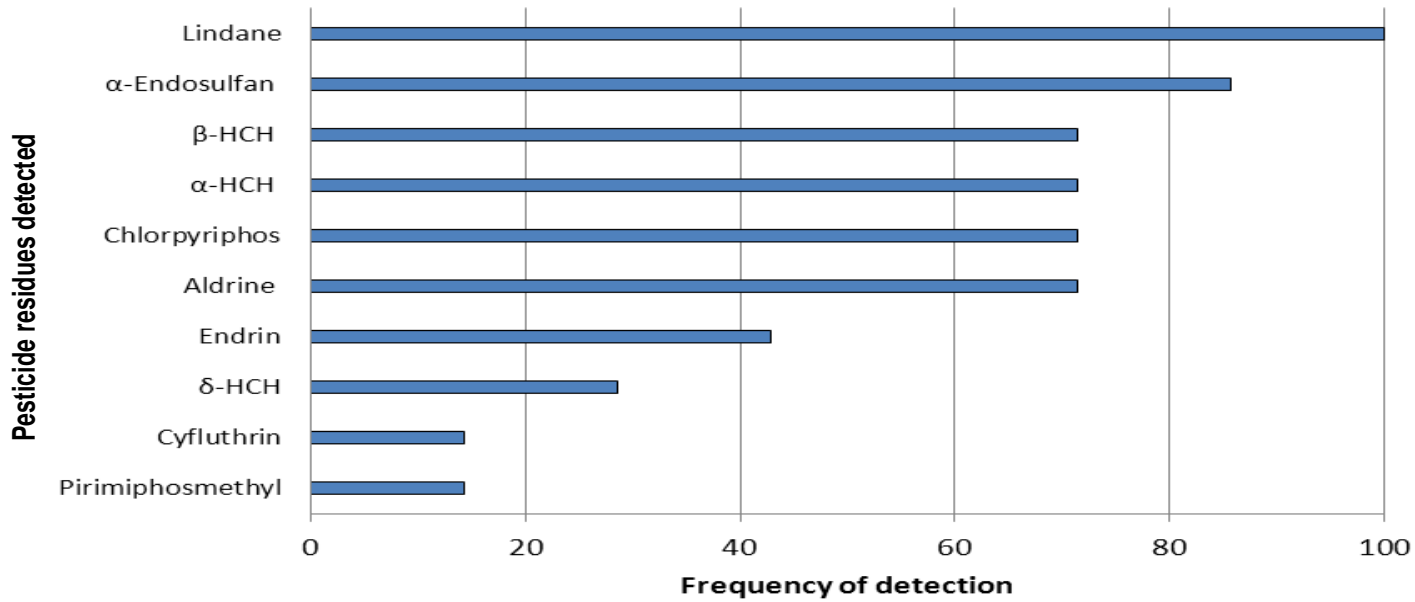

Figure 2. Presence of pesticide molecules in vegetable samples.

\section{Pesticide residue analysis}

Pesticide residue extraction and analysis concern active molecules (such as organochlorines, organophosphorines, carbamates and pyrethrinoids) most used in Togo (Kanda, 2011). Analytical grade reagents and solvents supplied by BDH Laboratory Supplies (England) were used.

$20 \pm 0.1 \mathrm{~g}$ of prepared matrix was weighed and introduced in a $100 \mathrm{ml}$ centrifuge tube. $40 \pm 0.2 \mathrm{ml}$ of ethyl acetate was added and macerated for 30 seconds. Anhydrous sodium sulphate $(20 \pm 0.1 \mathrm{~g})$ and sodium bicarbonate $(5 \pm 0.1 \mathrm{~g})$ were added and the mixture was macerated for $90 \mathrm{~s}$. The resulting solution is centrifuged at $2500 \mathrm{rpm}$ for $5 \mathrm{~min}$. A $10 \mathrm{ml}$ aliquot is placed in a $100 \mathrm{ml}$ roundbottomed flask and evaporated to $2 \mathrm{ml}$. The residue obtained is dissolved in $2 \mathrm{ml}$ of ethyl acetate before analysis. The extract was kept frozen until the end of the quantitative study.

The analyses of residues of pesticides were carried out using a Varian CP 380 GC chromatograph equipped with a capillary column $(30 \mathrm{~m} \times 0.25 \mathrm{~mm})$. Columns VF-5 $\mathrm{ms}$ and VF-1701 respectively were used for the quantification of organochlorinated and of organophosphorus compounds.

The identification of pesticides was done by calibration with standard solutions and comparison of retention indices of the standard solution peaks with those of the samples (vegetable, soil and water). The determination of pesticide residue concentrations was made from standard calibration curve solutions. These curves were established by tracing peak areas in accordance with the concentration of analysed pesticide. A correlation coefficient superior to 0.99 was obtained.

\section{Trace element investigation}

\section{Vegetable and water sampling}

Vegetable samples were taken under the conditions mentioned above. To assess the migration and accumulation of trace elements in the plants, the roots, stems and leaves of some species were sampled, packed in plastic bags and labelled. For each species, five (5) random samples were combined to form a composite sample. After, all samples were immediately transported to the laboratory. In addition, eight (8) composite water samples were collected in the coastal market garden fields (piezometers) or in the Zio river at Agoènyivé in polystyrene bottles that were previously cleaned with $10 \%$ nitric acid and thoroughly rinsed with distilled water (de Mora and Harrison, 1983).

\section{Pre-treatment of samples}

The vegetable samples were washed with tap water, rinsed with distilled water, weighed and dried in an oven at $70^{\circ} \mathrm{C}$ for $72 \mathrm{~h}$. The resulting dry material is weighed and then ground to a fine powder in a porcelain mortar. $2 \mathrm{~g}$ of the fine powder were introduced in a Teflon box, moistened with a little distilled water and then subjected to acid hydrolysis using a mixture of $10 \mathrm{ml}$ of hydrogen peroxide $(9 \%)$ and $6 \mathrm{ml}$ of concentrated nitric acid. The Teflon box containing the dissolved sample is closed with a watch glass and heated on a sand bath for about $1 \mathrm{~h} 30 \mathrm{~min}$ at about $150^{\circ} \mathrm{C}$. The pellet obtained after heating was dissolved in $2 \mathrm{ml}$ of $10 \% \mathrm{HNO}_{3}$ and reheated. After cooling, the solution obtained after acid digestion is transferred to a $50 \mathrm{ml}$ flask which was then filled with deionized water to the mark. After homogenization, the solution was filtered through a Whatman filter paper. The filtrate is collected in a $125 \mathrm{ml}$ bottle which was then tightly closed. The blank is prepared from 6 $\mathrm{ml}$ of concentrated nitric acid.

For the water samples, three drops of $1 \% \mathrm{HNO}_{3}$ were added to dissolve complex metals and analyzed without further treatment. The water was measured directly without treatment.

\section{Preparation of standard solutions}

The determination of a metal ion concentration by spectrophotometry is carried out after calibration of standard solutions. The concentrations of chosen standard solutions must lie within the ranges of the solutions to be analyzed. Standard solutions are obtained by diluting stock solutions supplied by Merck K Ga A.

\section{Determination of trace elements}

Trace element analysis was performed by atomic absorption spectrophotometry using a Thermo Electron Corporation S Series AA Spectrometer. The operating principle is based on the absorption of a beam of monochromatic light of given wavelength by a chemical when the latter is sent into an atomic vapour obtained by spraying into a flame. An aqueous solution containing metallic ions is vaporized into the flame to give neutral atoms. These atoms, by absorption of light rays of specific wavelength attain a higher 
Table 1. Analysed vegetable species.

\begin{tabular}{|c|c|c|c|c|}
\hline Species & Families & Samplings & $\begin{array}{c}\text { Samplings for } \\
\text { pesticide residues } \\
\text { research }\end{array}$ & $\begin{array}{l}\text { Samplings for } \\
\text { trace elements } \\
\text { research }\end{array}$ \\
\hline Beta vulgaris L. & Chenopodiaceae & Tuber & + & \\
\hline Allium cepa L. & Alliaceae & Bulb & + & \\
\hline Brassica oleracea L. var. botrytis & Brassicaceae & Inflorescence & & + \\
\hline B. oleracea L. var. capitata & Brassicaceae & Leaf (stem, root) & & + \\
\hline Capsicum annuum L. & Solanaceae & Fruit & + & \\
\hline Capsicum annuum L. & Solanaceae & Fruit & & + \\
\hline Corchorus olitorius L. & Tiliaceae & Leaf (stem, root) & + & + \\
\hline Daucus carota L. & Umbelliferae & Tuber & + & + \\
\hline Lactuca sativa L. & Asteraceae & Leaf & + & + \\
\hline Phaseolus vulgaris $\mathrm{L}$. & Papilionaceae & Fruit & & + \\
\hline Lycopersicum esculentum L. & Solanaceae & Fruit & + & \\
\hline Solanum macrocarpum L. & Solanaceae & Leaf (stem, root) & & + \\
\hline
\end{tabular}

+ : Concerned species and samplings.

energy level. By measuring the light intensity before and after its passage through the atomic vapour, the concentration of the solution under study is determined. To attain this objective, the beam of incident light must be sufficiently intense.

Concentrations of trace elements were determined and expressed in $\mathrm{mg} / \mathrm{kg}$ for vegetable samples and in $\mathrm{mg} / \mathrm{L}$ for water samples.

\section{Statistical analysis and calibration}

The different results were processed using Microsoft Excel Software $^{\mathrm{TM}}$. Descriptive statistics (number of observations, percentage detection, maximum, average and median values) were calculated.

Significant tests were carried out using the analysis of variance (ANOVA) of the statistical package for social sciences (SPSS Version 17) computer program.

The results marked as "traces" or "not detected" were replaced by zero. The objective was to determine whether the pesticide residues and trace elements in vegetables, soil and water samples could be risky to human health. The benchmark references used are those of the WHO $(1993,1998)$ for pesticide residues in drinking water and vegetables, and for trace elements Public Health Council of France (1996), FAO and WHO (2001), and European Commission (2001) standards were used for cadmium and lead. For copper and nickel, data from Kabata-Pendias and Pendias (2001) were used.

Certified standards (Perkin, 1999) of 100 ppm were used to build calibration curves for each metal. Detection limit was established for each element as estimated from the variance of the zero ordinate for the calibration data of each metal.

\section{RESULTS}

\section{Pesticide residue contamination}

Analyses of vegetable samples reveal contamination by different groups of pesticides. These are mostly organochlorines (Figure 2) such as lindane $(100 \%$ detection), $\alpha$-endosulfan (85.71\%), $\alpha-\mathrm{HCH}, \quad \beta-\mathrm{HCH}$, chlorpyriphos and aldrin. These molecules are found in at least five (5) vegetable species (Table 2).

Some examples of the mean concentration coefficient and the maximum allowed residue limits are shown in Table 3. The concentrations of $\alpha$-endosulfan, lindane, chlorpyriphos, aldrin, $\alpha-\mathrm{HCH}$ and $\beta-\mathrm{HCH}$ were analysed with coefficient 1.5 to 10 in Lactuca sativa. In Daucus carota and Corchorus olitorius, a-endosulfan was analysed with coefficient of 2. Capsicum annuum contains $\alpha$ $\mathrm{HCH}$ and $\beta-\mathrm{HCH}$ with coefficient of 5 .

For all pesticide molecules investigated, the concentrations are less than $20 \mathrm{mg} / \mathrm{kg}$ of dry material. These molecules were herbicides $(56.76 \%)$, insecticides $(32.43 \%)$ and fungicides (10.81\%) (Table 4).

The analyses revealed that water in the market garden fields is contaminated by pesticides (Table 5). Different molecules of pesticides were detected but all were under $0.05 \mu \mathrm{g} / \mathrm{L}$. Some pesticides such as metalaxyl M (0.06 $\mu \mathrm{g} / \mathrm{L}$ and $1.1 \mu \mathrm{g} / \mathrm{L})$ and dimethoate $(1 \mu \mathrm{g} / \mathrm{L})$ were detected in larger concentrations.

\section{Trace element contamination}

Trace element accumulations vary with vegetable species (Figure 3). Of all trace elements investigated, copper content is highest in all species. Its average concentration ranges from 1.86 to $9.32 \mathrm{mg} / \mathrm{kg}$ of dry matter. Nickel and lead are noted in some species such as $C$. olitorius, Brassica oleracea var. capitata, C. annuum, Phaseolus vulgaris and Brassica oleracea var. botrytis. Nickel concentrations range from 0.238 to $1.509 \mathrm{mg} / \mathrm{kg}$. Lead is detected in doses from 0.171 to $4.006 \mathrm{mg} / \mathrm{kg}$.

The mean levels of trace elements in different Vegetable species and the over-concentration factors (CF) where appropriate are presented in Table 6. 
Table 2. Mean concentrations of pesticide residues in vegetable species.

\begin{tabular}{|c|c|c|c|c|c|c|c|c|c|c|c|}
\hline \multirow{2}{*}{$\begin{array}{l}\text { Vegetable } \\
\text { species }\end{array}$} & \multirow{2}{*}{$\begin{array}{l}\text { Mean concentration and } \\
\text { Maximum residues Limits }\end{array}$} & \multicolumn{10}{|c|}{ Pesticides residues mean concentration $(\mathrm{mg} / \mathrm{kg})$} \\
\hline & & a-Endosulfan & Lindane & Chlorpyriphos & Aldrin & Endrin & $\alpha-\mathrm{HCH}$ & $\beta-\mathrm{HCH}$ & ठ-HCH & Cyfluthrin & Pyrimiphos-methyl \\
\hline \multirow{2}{*}{ A. сера } & TM & 0.06 & 0.05 & 0.05 & 0.055 & 0.01 & 0.1 & 0.1 & 0.01 & - & - \\
\hline & LMR & 0.1 & - & 0.2 & - & 0.1 & - & - & - & 0.2 & - \\
\hline \multirow{2}{*}{ L. sativa } & TM & 0.075 & 0.05 & 0.075 & 0.05 & 0.01 & 0.1 & 0.1 & 0.01 & - & 0.05 \\
\hline & LMR & 0.05 & 0.01 & 0.05 & 0.01 & 0.01 & 0.01 & 0.01 & 0.01 & - & 0.05 \\
\hline \multirow{2}{*}{ C. annuum } & TM & 0.05 & 0.05 & 0.05 & 0.05 & - & 0.1 & 0.1 & - & - & - \\
\hline & LMR & 0.05 & 0.5 & 0.05 & 0.1 & - & $<0.02$ & $<0.02$ & - & - & - \\
\hline \multirow{2}{*}{ D. carota } & TM & 0.1 & 0.1 & 0.1 & 0.1 & - & 0.1 & 0.1 & - & - & - \\
\hline & LMR & 0.05 & - & 0.1 & - & - & - & - & - & - & - \\
\hline \multirow{2}{*}{ C. olitorius } & TM & 0.1 & 0.1 & 0.1 & 0.1 & - & 0.1 & 0.1 & - & - & - \\
\hline & LMR & 0.05 & - & - & - & - & - & - & - & - & - \\
\hline \multirow{2}{*}{ L. esculentum } & TM & 0.01 & 0.01 & - & - & 0.01 & - & - & - & - & - \\
\hline & LMR & 0.05 & 0.01 & - & - & 0.01 & - & - & - & - & - \\
\hline \multirow{2}{*}{ B. vulgaris } & TM & - & 0.01 & - & - & - & - & - & - & $<0.02$ & - \\
\hline & LMR & - & 0.01 & - & - & - & - & - & - & $<0.02$ & - \\
\hline
\end{tabular}

Table 3. Mean concentration of pesticide residues in vegetable species and over-concentration factors (CF).

\begin{tabular}{|c|c|c|c|c|c|c|c|c|c|c|c|c|c|}
\hline \multirow{2}{*}{$\begin{array}{l}\text { Vegetable } \\
\text { species }\end{array}$} & \multirow{2}{*}{$\begin{array}{l}\text { Mean concentration and } \\
\text { maximum residues limits }\end{array}$} & \multicolumn{12}{|c|}{ Pesticides residues mean concentration $(\mathrm{mg} / \mathrm{kg})$} \\
\hline & & a-Endosulfan & CF & Lindane & CF & Chlorpyriphos & CF & Aldrine & $\mathbf{C F}$ & $\mathrm{aHCH}$ & CF & $\beta \mathrm{HCH}$ & CF \\
\hline \multirow{2}{*}{ L. sativa } & TM & 0.075 & 1.5 & 0.05 & 5 & 0.075 & 1.5 & 0.05 & 5 & 0.1 & 10 & 0.1 & 10 \\
\hline & LMR & 0.05 & & 0.01 & & 0.05 & & 0.01 & & 0.01 & & 0.01 & \\
\hline \multirow{2}{*}{ C. annuum } & TM & 0.05 & 1 & 0.05 & 0.1 & 0.05 & & 0.05 & & 0.1 & 5 & 0.1 & 5 \\
\hline & LMR & 0.05 & & 0.5 & & 0.05 & & 0.1 & & 0.02 & & 0.02 & \\
\hline \multirow{2}{*}{ D. carota } & $\mathrm{TM}$ & 0.1 & 2 & 0.1 & & 0.1 & & 0.1 & & 0.1 & & 0.1 & \\
\hline & LMR & 0.05 & & - & & 0.1 & & - & & - & & - & \\
\hline \multirow{2}{*}{ C. olitorius } & $\mathrm{TM}$ & 0.1 & 2 & 0.1 & & 0.1 & & 0.1 & & 0.1 & & 0.1 & \\
\hline & LMR & 0.05 & & - & & - & & - & & - & & - & \\
\hline
\end{tabular}


Table 4. Soil content of pesticide residues.

\begin{tabular}{|c|c|c|c|}
\hline Pesticide detected & Class & Chemical family & Average content $(\mu \mathrm{g} / \mathrm{kg})$ \\
\hline Cyprodinil & $\mathrm{F}$ & Anilinopyrimidins & $<20$ \\
\hline Kresoxim-methyl & $\mathrm{F}$ & Strobulirins & $<20$ \\
\hline Flusilazol & $\mathrm{F}$ & Triazols & $<20$ \\
\hline Tebuconazol & $\mathrm{F}$ & Triazols & $<20$ \\
\hline Alachlor & $\mathrm{H}$ & Chloroacetamid & $<20$ \\
\hline Metazachlor & $\mathrm{H}$ & Chloroacetamid & $<20$ \\
\hline Metolachlor & $\mathrm{H}$ & Chloroacetamid & $<20$ \\
\hline Clodinofop-Propargyl & $\mathrm{H}$ & Aryloxyphenoxy-propionates & $<20$ \\
\hline Tebutam & $\mathrm{H}$ & Benzamid & $<20$ \\
\hline Ethofumesate & $\mathrm{H}$ & Benzofuran & $<20$ \\
\hline Aclonifen & $\mathrm{H}$ & Diphenulethers & $<20$ \\
\hline Bromoxynil octanoate & $\mathrm{H}$ & Hydroxybenzonitrils & $<20$ \\
\hline Oxadiazon & $\mathrm{H}$ & Oxadiazols & $<20$ \\
\hline Diflufenican & $\mathrm{H}$ & Pyridinecarboximids & $<20$ \\
\hline Triallat & $\mathrm{H}$ & Thiocarbamate & $<20$ \\
\hline Trifluralin & $\mathrm{H}$ & Toluidin & $<20$ \\
\hline Atrazine & $\mathrm{H}$ & Triazene & $<20$ \\
\hline Desmetryn & $\mathrm{H}$ & Triazene & $<20$ \\
\hline Prometryne & $\mathrm{H}$ & Triazene & $<20$ \\
\hline Propazin & $\mathrm{H}$ & Triazene & $<20$ \\
\hline Simazine & $\mathrm{H}$ & Triazene & $<20$ \\
\hline Terbuthylazine & $\mathrm{H}$ & Triazene & $<20$ \\
\hline Terbutryn & $\mathrm{H}$ & Triazene & $<20$ \\
\hline Metribuzin & $\mathrm{H}$ & Triazene & $<20$ \\
\hline Epoxiconazol & $\mathrm{H}$ & Triazoles & $<20$ \\
\hline Aldrin & 1 & $\mathrm{OC}$ & $<20$ \\
\hline Alfa $\mathrm{HCH}$ & I & OC & $<20$ \\
\hline Alpha endosulfan & I & OC & $<20$ \\
\hline Beta endosulfan & I & OC & $<20$ \\
\hline Beta $\mathrm{HCH}$ & I & $\mathrm{OC}$ & $<20$ \\
\hline Dieldrin & I & OC & $<20$ \\
\hline Gama HCH (Lindane) & I & OC & $<20$ \\
\hline (Hexachlorobenzen) & I & OC & $<20$ \\
\hline Heptachlor & I & OC & $<20$ \\
\hline Heptachlorepoxyd & I & OC & $<20$ \\
\hline Chlorpyriphos ethyl & I & OP & $<20$ \\
\hline Lambda-cyhalothrin & $\mathrm{I}$ & PS & $<20$ \\
\hline
\end{tabular}

F: fungicide, I: insecticide, H: herbicide, OC: Organochlorinated compound, OP: organophosphorus compound, PS: pyrethrinoid

Table 5. Significant concentrations of pesticide residues detected in water $(\mu \mathrm{g} / \mathrm{L})$.

\begin{tabular}{lcc}
\hline Pesticides detected & Well $\mathbf{1}$ & Well 3 \\
\hline Métalaxyl M & 1.10 & 0.06 \\
Diméthoate & - & 1.00 \\
\hline
\end{tabular}

Trace element over-concentration was observed in all species except $B$. oleracea var. botrytis. It reaches 3 times the maximum acceptable value for copper in $D$. carota and Solanum macrocarpum. This contamination in trace metals is especially observed for nickel and lead for which over-concentration can reach 30 (in $S$. macrocarpum for nickel) to 40 times (in P. vulgaris for 


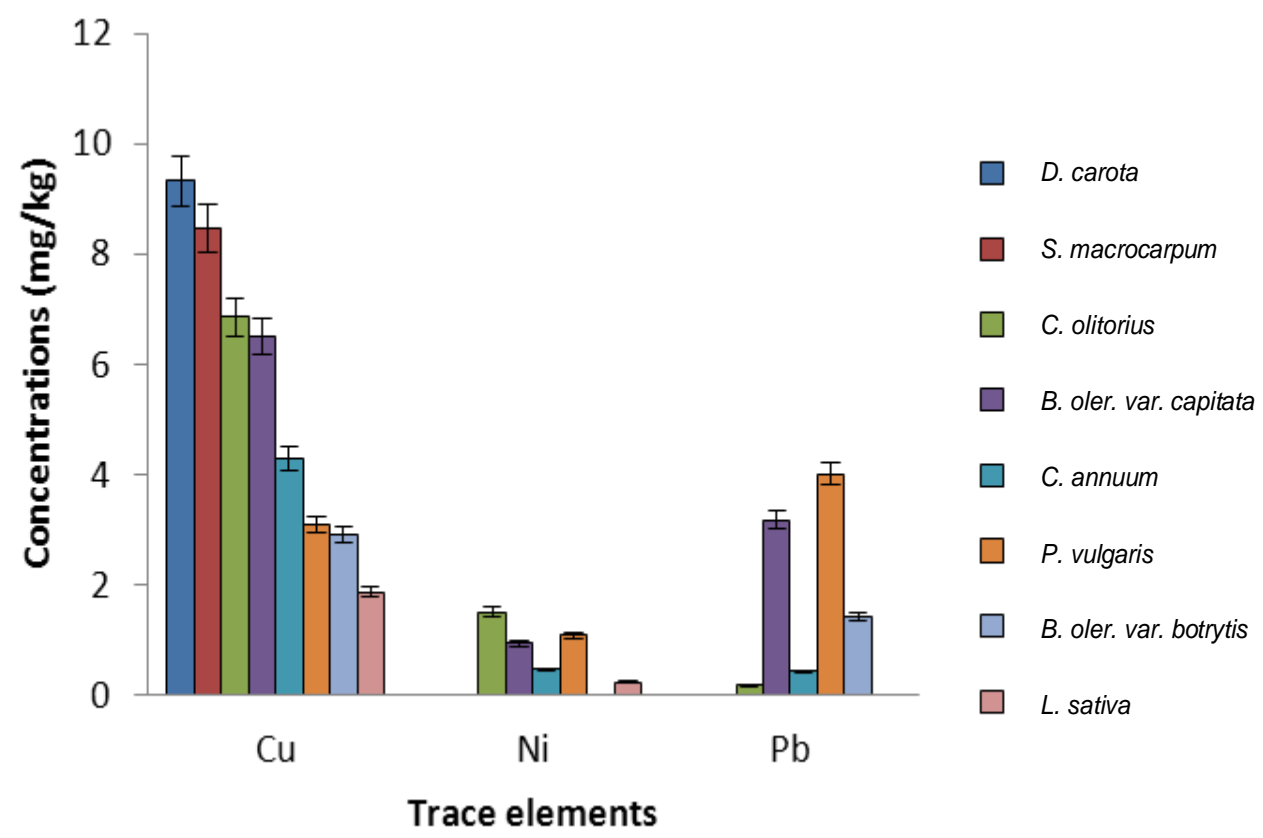

Figure 3. Content of trace elements in the vegetable species.

Table 6. Mean concentrations of trace element (MC) in vegetables and over-concentration factors (CF).

\begin{tabular}{lcccccc}
\hline \multirow{2}{*}{ Vegetable species } & \multicolumn{2}{c}{ Copper } & \multicolumn{2}{c}{ Nickel } & \multicolumn{2}{c}{ Lead } \\
\cline { 2 - 7 } & MC & CF & MC & CF & MC & CF \\
\hline D. carota & $9.32 \pm 2.98$ & 3 & - & - & - & - \\
S. macrocarpum & $8.46 \pm 0.581$ & 3 & $1.51 \pm 0.045$ & 30 & $0.17 \pm 0.024$ & 1.5 \\
C. olitorius & $6.86 \pm 2.68$ & 2 & $0.48 \pm 0.052$ & 5 & - & - \\
B. oleracea var. capitata & $6.52 \pm 1.53$ & 2 & $0.93 \pm 0.012$ & 19 & $3.18 \pm 0.53$ & 32 \\
C. annuum & $4.28 \pm 1.096$ & 1 & 0 & 0 & $1.41 \pm 1.032$ & 14 \\
P. vulgaris & $3.10 \pm 1.082$ & 1 & $1.09 \pm 0.235$ & 22 & $4.01 \pm 1.752$ & 40 \\
B. oleracea var. botrytis & $2.93 \pm 0.085$ & 1 & - & - & - & - \\
L. sativa & $1.86 \pm 0.354$ & 0.5 & $0.47 \pm 0.01$ & 9 & $0.42 \pm 0.021$ & 4 \\
FAO/WHO (2001) & $3 \pm 0.861$ & - & $0.05 \pm 0.012$ & & $0.1 \pm 0.02$ & \\
\hline
\end{tabular}

lead).

Trace element concentrations vary according to organs (leaf, root, stem, inflorescence, fruit and tuber) of vegetable species (Table 7). The leaves of $S$. macrocarpum, $C$. olitorius, $B$. oleracea var. oleracea, $B$. oleracea var. botrytis and D. carota accumulate copper in concentrations of $14.13 \mathrm{mg} / \mathrm{kg}$ to $1.82 \mathrm{mg} / \mathrm{kg}$. Leaves of $B$. oleracea var. botrytis also contain nickel at 0.16 $\mathrm{mg} / \mathrm{kg}$. Inflorescences of $B$. oleracea var. botrytis can accumulate copper at $2.92 \mathrm{mg} / \mathrm{kg}$ and lead at $1.42 \mathrm{mg} / \mathrm{kg}$. Fruits of $C$. olitorius could contain $1.23 \mathrm{mg} / \mathrm{kg}$ of copper and the tubers of $D$. carota accumulate copper at a concentration of $9.32 \mathrm{mg} / \mathrm{kg}$.

The species that accumulate the most trace elements are $B$. oleracea var. capitata, $C$. annuum, $C$. olitorius and $L$. sativa. They are vegetables that are much appreciated by city dwellers (Table 8). They accumulate copper, nickel and lead. Their presence in city surroundings can be explained by the fact that these areas were used as rubbish dumps. High levels of copper at Kara $(4.46 \mathrm{mg} / \mathrm{kg}$ for C. olitorius, 13.15 for B. oleracea var. capitata and $22.62 \mathrm{mg} / \mathrm{kg}$ for $S$. macrocarpum) could be explained by the closeness of market garden fields on the banks of the Kara River to an electric power plant whose waste oils are dumped in the river. The accumulation of lead (9.53 $\mathrm{mg} / \mathrm{kg}$ for B. oleracea var. capitata) at the high altitude of Danyi may be explained by a probable geological origin. This contamination could also be due to the application of agrochemicals to cocoa and coffee fields located in this part of the country.

Water samples from the coast and the Zio River contain lead at levels ranging from 0.018 to $0.194 \mathrm{mg} / \mathrm{L}$ of 
Table 7. Trace element accumulation in different parts of vegetable species.

\begin{tabular}{|c|c|c|c|c|c|c|c|}
\hline Element & Vegetable species & Leaf & Root & Stem & Flowers & Fruit & Tuber \\
\hline \multirow{5}{*}{$\mathrm{Cu}$} & S. macrocarpum & $14.13 \pm 1.72$ & $4.16 \pm 2.001$ & $6.92 \pm 1.01$ & 0 & 0 & 0 \\
\hline & C. olitorius & $4.46 \pm 0.85$ & $2.21 \pm 1.96$ & 0 & 0 & $1.23 \pm 0.356$ & 0 \\
\hline & B. oleracea var. capitata & $13.15 \pm 4.289$ & $8.8 \pm 1.847$ & $3.57 \pm 0.92$ & 0 & 0 & 0 \\
\hline & B. oleracea var. botrytis & $13.55 \pm 2.87$ & 0 & 0 & $2.92 \pm 0.86$ & 0 & 0 \\
\hline & D. carota & $1.82 \pm 0.28$ & 0 & 0 & 0 & 0 & $9.32 \pm 2.834$ \\
\hline $\mathrm{Ni}$ & B. oleracea var. capitata & $0.16 \pm 0.12$ & 0 & 0 & 0 & 0 & 0 \\
\hline \multirow{2}{*}{$\mathrm{Pb}$} & S. macrocarpum & 0 & 0 & $0.69 \pm 0.071$ & 0 & 0 & 0 \\
\hline & B. oleracea var. botrytis & 0 & 0 & 0 & $1.41 \pm 0.487$ & 0 & 0 \\
\hline
\end{tabular}

Table 8. Mean concentration in trace element in vegetable species from different provenances.

\begin{tabular}{clccccc}
\hline Element & Provenance & B. oleracea var. capitata & C. annuum & C. olitorius & L. sativa & S. macrocarpum \\
\hline \multirow{4}{*}{} & Lomé & $2.67 \pm 1.81$ & $4.89 \pm 1.253$ & $7.54 \pm 0.59$ & 0 & $5.63 \pm 1.001$ \\
& Kara & $13.15 \pm 1.94$ & 0 & $4.46 \pm 1.81$ & 0 & $22.62 \pm 1.84$ \\
$\mathrm{Cu}$ & Dapaong & $0.17 \pm 0.011$ & $4.5 \pm 0.965$ & 0 & $1.93 \pm 0.61$ & 0 \\
& Agoè & 0 & 0 & $7.13 \pm 1.42$ & 0 & 0 \\
& Aného & 0 & $3.78 \pm 2.83$ & 0 & 0 & 0 \\
& Danyi & $1.09 \pm 0.81$ & 0 & 0 & 0 & 0 \\
& Kouméa & 0 & 0 & 0 & $1.57 \pm 0.87$ & 0 \\
& Kpissidè & 0 & $3.87 \pm 0.62$ & 0 & 0 & 0 \\
& Dapaong & $0.28 \pm 0.04$ & $1.94 \pm 0.016$ & 0 & $0.16 \pm 0.01$ & 0 \\
& Lomé & $3.62 \pm 1.028$ & 0 & 0 & 0 & 0 \\
$\mathrm{Ni}$ & Agoè & 0 & 0 & $2.64 \pm 0.67$ & 0 & 0 \\
& Danyi & $1.33 \pm 0.441$ & 0 & 0 & 0 & 0 \\
& Kara & $0.16 \pm 0.012$ & 0 & 0 & 0 & 0 \\
& Kouméa & 0 & 0 & 0 & $0.57 \pm 0.05$ & 0 \\
& Kpissidè & 0 & $0.86 \pm 0.95$ & 0 & 0 & 0 \\
$\mathrm{~Pb}$ & Lomé & 0 & 0 & $0.30 \pm 0.02$ & 0 & 0 \\
& Danyi & $9.53 \pm 2.865$ & 0 & 0 & 0 & 0 \\
& Kpissidè & 0 & $2.54 \pm 1.54$ & 0 & 0 & 0 \\
\hline
\end{tabular}

water (Table 9). The highest concentrations $(0.025$ to $0.032 \mathrm{mg} / \mathrm{L}$ ) are found in the Zio. However, nickel has been detected only in samples from the Zio and cadmium levels of 0.077 to $0.084 \mathrm{mg} / \mathrm{L}$. Under our operating conditions, copper was not detected in any water sample. Lead pollution in drinking water was 2 to 19 times the maximum value allowed by the WHO. The concentrations of cadmium are 26 to 28 times higher than the maximum value allowed by the $\mathrm{WHO}$.

\section{DISCUSSION}

\section{Pesticide contamination}

Molecules detected in vegetable samples are mainly organochlorines. Studies carried out in Togo (Djaneye-
Boundjou et al., 2000), Ghana (Ntow, 2001), Senegal, Gambia (Cissé et al., 2003; Manirakiza et al., 2003) and Benin (Assogba-Komlan et al., 2007) showed contamination of tubers, fruits and vegetables by various pesticide residues in which organochlorines are the major components.

It was shown that pesticide residues are accumulated in the soil and then pass to the plant through the roots (Fismes et al., 2002; Otani et al., 2007). Apart from $A$. cepa, B. oleracea and $C$. annuum (white pepper), the levels of contamination of other vegetables (such as $D$. carota, C. olitorius, L. esculentus and B. vulgaris) do not seem to present a danger to human health according to EU/UNIDO/UEMOA (2005) standards. However, the study shows contaminations of vegetables, water and soil but it was not possible to determine long-term effects 
Table 9. Mean concentration (MC) in trace element (mg/L) in water and over-concentration factors (CF).

\begin{tabular}{|c|c|c|c|c|c|c|c|c|c|}
\hline Element & $\begin{array}{l}\text { Concentration } \\
\text { and factor }\end{array}$ & $\begin{array}{c}\text { River Zio } \\
1 \\
\end{array}$ & $\begin{array}{c}\text { River Zio } \\
3 \\
\end{array}$ & $\begin{array}{c}\text { River Zio } \\
2 \\
\end{array}$ & $\begin{array}{c}\text { Well } \\
3 \\
\end{array}$ & $\begin{array}{c}\text { Well } \\
4 \\
\end{array}$ & $\begin{array}{c}\text { Well } \\
5 \\
\end{array}$ & $\begin{array}{c}\text { Well } \\
1 \\
\end{array}$ & $\begin{array}{c}\text { Well } \\
2 \\
\end{array}$ \\
\hline \multirow{2}{*}{$\mathrm{Ni}$} & $\mathrm{MC}$ & $0.025 \pm 0.01$ & $0.029 \pm 0.001$ & $0.032 \pm 0.012$ & 0 & 0 & 0 & 0 & 0 \\
\hline & CF & 0.4 & 0.5 & 0.5 & 0 & 0 & 0 & 0 & 0 \\
\hline \multirow{2}{*}{$\mathrm{Pb}$} & $\mathrm{MC}$ & $0.194 \pm 0.023$ & $0.187 \pm 0.047$ & $0.152 \pm 0.02$ & $0.135 \pm 0.02$ & $0.093 \pm 0.032$ & $0.081 \pm 0.04$ & $0.036 \pm 0.021$ & $0.018 \pm 0.01$ \\
\hline & CF & 19 & 18 & 15 & 14 & 9 & 8 & 4 & 2 \\
\hline \multirow{2}{*}{$\mathrm{Cd}$} & MC & 0 & 0 & 0 & $0.079 \pm 0.034$ & $0.084 \pm 0.011$ & $0.077 \pm 0.02$ & $0.081 \pm 0.012$ & $0.082 \pm 0.011$ \\
\hline & $\mathrm{CF}$ & 0 & 0 & 0 & 26 & 28 & 26 & 27 & 27 \\
\hline
\end{tabular}

on living organisms and ecosystem function. It is clear that the absorption of pesticide residues present in market garden produce may present a risk of poisoning when consumption is associated with a regular intake in small doses (Kamdem and Fofiri, 2008).

This study is comparable to those of Cissé et al. (2003) and Traoré et al. (2006) who have also detected in wells, vegetables and in banana and pineapple plantations, higher concentrations of pesticides such as endosulfan, chlorpyrifos-ethyl and $\mathrm{HCH}$ than those obtained in this study. Mawussi (2008) and Gamboa-Rodríguez et al. (2012) noted organochlorines in river water and wells at levels exceeding the maximum recommended by the $\mathrm{FAO}$, WHO and European Union. This kind of water contamination is mentioned throughout Africa (Ntow, 2001; Ntow, 2005; Mwevura et al., 2002; Cissé et al., 2003; Kishimba et al., 2004). Indeed, Richard and Giroux (2004) demonstrated that the presence of pesticides in water could be responsible for stream degradation and could also affect human health (Hayat et al., 2010).

\section{Trace element contamination}

These results compared to WHO standards on vegetables and drinking water, show values exceeding the maximum allowable concentrations for copper, nickel, lead and cadmium whatever the sample point (Public Health Council of France, 1996; Commission européenne, 2001). The contamination could be due to the use of pesticides and chemical fertilizers (Derwich et al., 2008; Adam et al., 2010). The highest and most frequent concentrations were those of copper and lead in vegetables and cadmium in water. Copper comes from copper fungicides (Delas, 1963 Shtangeeva, 2005; SOGREAH, 2007). Organic fertilizers also contain high concentrations of copper and zinc (Jondreville et al., 2002; Levasseur, 2002; Marcato, 2007); while phosphatic fertilizers were rich in cadmium (Nicholson et al., 2003; Shtangeeva, 2005 SOGREAH, 2007). Trace elements are often concentrated in animal manures because they are not assimilated by animals. Kouakou et al. (2008) and Boukhari and Rada (2000) showed that poultry manures are a source of trace metal enrichment of soils and their bioavailability could be enhanced by soil acidity. These manures are used in Togolese market gardens (Kanda, 2011). The banks of the Zio River are dumpsites for household and factory waste, a factor that could also facilitate contamination. Coastal soils have low cation exchange capacity which could also facilitate trace element transfer to the environment (Denaix, 2007). According to Tremella-Schaub and Feix (2005), soil-plant transfer of lead is negligible compared to the direct deposition of dust containing lead on the aerial parts of plants especially in urban areas or along roads with heavy traffic. In Nigeria, Atayese et al. (2008) have shown that vegetables grown along highways contain lead (68 to $152 \mathrm{mg} / \mathrm{kg}$ ) and cadmium ( 0.5 to $4.9 \mathrm{mg} / \mathrm{kg}$ )

The study showed that the aerial parts of vegetables contain more copper. Cadmium was only detected in water as also noted by Niang (1996). Cadmium is very soluble in water and can migrate in its soluble form from the surface to the phreatic layer (Camobreco et al., 1996; Ablain, 2002). However, even if these recorded concentrations can cause acute toxicity, it is important to point out that the ecotoxicological risks reside in their bioaccumulation (TarrasWahlberg et al., 2001; Ramade 1992; Cheggour et al., 1999).

\section{Conclusion}

This study allows us to state that agrochemical 
application could pollute agro products like vegetables, and could be present in the soil and groundwater. In vegetables, the notable molecules are lindane, $\alpha$ endosulfan, $\alpha-\mathrm{HCH}, \beta-\mathrm{HCH}$, chlorpyriphos and aldrin. In soils, contaminations are below $20 \mathrm{mg} / \mathrm{kg}$. Water contamination is significant in coastal wells where metalaxyl $\mathrm{M}$ at $0.06 \mu \mathrm{g} / \mathrm{L}$ and $1.1 \mu \mathrm{g} / \mathrm{L}$ and dimethoate at $1 \mu \mathrm{g} / \mathrm{L}$ are detected.

Trace element levels vary according to vegetable species from 1.86 to $9.32 \mathrm{mg} / \mathrm{kg}$ of dry matter. $B$. oleracea var. botrytis inflorescences accumulate copper and lead; the fruits $C$. olitorius could contain copper and $D$. carota tubers, copper. These results also depend on sample origin. Water samples could be contaminated by trace elements and this kind of pollution could reach 28 times higher considering WHO recommendations.

All kinds of pollution in garden market fields could be reduced if some precautions were taken. Amongst them, best practices in commercialization and application of agrochemicals could be noted. Market gardeners may be advised on ways of applying agrochemicals that are suited to this kind of agriculture. In this way, they could contribute positively to the implementation of the National Program for Agricultural Investment and Food Security (NPAIFS).

\section{AKNOWLEDGEMENTS}

The authors appreciate translation support from Mr. Wilson B. Tetevi. The research was supported by a grant of the United Nations Educational, Scientific and Cultural Organization (UNESCO) Keizo Obuchi Fellowship Programme - 2009 to Mme Kanda Madjouma.

\section{RERERENCES}

Ablain $F$ (2002). Role of earthworm activity on the redistribution of trace metals from sewage sludge in an agricultural soil. PhD Thesis, Univ. Rennes 1, UMR ECBIO p. 256.

Adam S, Edorh PA, Totin H, Koumolou L, Amoussou E, Aklikokou K, Boko M (2010). Pesticides and heavy metals in drinking water, soils and sediments of the cotton belt of Gogounou, and Banikoara Kandi (Benin). Int. J. Biol. Chem. Sci. 4(4):1170-1179.

Agunwamba JC (2001). Analysis of socioeconomic and environmental impacts of waste stabilization pond and unrestricted wastewater irrigation: Interface with maintenance. Environ. Manag. 27(3):463476.

Assogba-Komlan F, Anihouvi P, Achigan E, Sikirou R, Boko A, Adje C, Ahle V, Vodouhe R, Assa A (2007). Agricultural practices and antinutrients content (nitrates and pesticides) of Solanum macrocarpum in southern Benin. Afr. J. Food Agric. Nutr. Dev. 7:21.

Atayese MO, Eigbadon AI, Oluwa KA, Adesodun JK (2008). Heavy metal contamination of Amaranthus grown along major highways in Lagos. Afr. Crop. Sci. J. 16(4):225-235.

Bahri A (2001). Urban and periurban water-related relationships: Closing the loops. Environ. Manag. Health.12:364-376.

Boukhari L, Rada A (2000). Cadmium exposure of plants grown on Moroccan calcareous soils amended with sludge and wastewater. Environ. Technol. 21:641-652.

Bouzid M, Ducrot R, Chagas de Carvalho YM, Imbernon RAL (2005).
Periurban agriculture dynamic and integrated water management: the case of a water catchment in the metropolitan area of São Paulo (Brazil). Cah. Agric. 14(1):131-137.

Camobreco VJ, Richards BK, Steenhuis TS, Peverly JH, McBride MB (1996). Movement of heavy metals through undisturbed and homogenized soil columns. Soil Sci. 161:740-750.

Cheggour M, Chafic A, Texier H (1999). Bioaccumulation of some metallic elements in the oyster Crassostrea gigas (Thunb.) farmed in the lagoon of Oualidia (Morocco): role of ecological and biological factors. French. Soc. Malac. 28:31-44.

Cissé I, Tandia AA, Touré Fall S, Diop (EI Hadji) S (2003). Uncontrolled use of pesticides in urban agriculture: the case of Niayes in Senegal. Cah. Agric.12(3):181-186.

Commission Européenne (2001). Regulation No. 466/2001 of the Committee of 08 March 2001 setting maximum levels for certain contaminants in foodstuffs. Official J. Eur. Commun. 16 March 2001 p. 13.

De Mora SJ, Harrison RM (1983). The use of physical separation techniques in trace metal speciation studies. Water Res. 17:723-733

Delamarche M (2007). Urban agriculture, cities that are ruralising. Trop. Mediter. Mark. 3212:5-6.

Delas J (1963). Toxicity of copper accumulated in soils. Agrochim 7:257-288.

Denaix $L$ (2007). Soil-water-plant trace elements transfer in cultivated and contaminated ecosystems. HDR Memoire, University of Pau and Pays de l'Adour p. 117.

Derwich E, Beziane Z, Benaabidate L, Belghyti D (2008). Assessing the quality of surface water from Fez Sebou wadis used in gardening in Morocco. Larhyss. J. 7:59-77.

Dieye BM (2006). Le financement de la production maraîchère : l'exemple de la zone de Potou (Sénégal). BIM 15:6.

Djaneye-Boundjou G, Bawa LM, Boukari Y (2000). Organochlorinated pesticide residues in vegetable food. Microbiol. Hyg. Alim. 12:42-46.

FAO, WHO (2001). Report on the $32^{\text {nd }}$ session of the Codex Committee on Food Additives and Contaminants, ALINORM 01/12, Beijing, People's Republic of China, 20-24 March 2000. Joint FAOMHO Food Standard Program, Codex Alimentarius Commission, 24th Session, 2-7 July, Geneva, Switzerland.

Fismes J, Perrin-Ganier C, Empereur-Bissonnet P, Morel JL (2002). Soil-to-roottransfer and translocation of polycyclic aromatic hydrocarbons by vegetables grown on industrial contaminated soils. J. Environ. Qual. 31:1649-1656.

Gamboa-Rodríguez T, Gamboa-Adeco R, Saldívar-Osorio L, GómezCruz $R$ (2012). Metals in water samples from an urban lagoon in Tabasco, Mexico. Afr. J. Environ. Sci. Technol. 6(3):170-175.

Gerstl S (2001). The economic costs and impact of home gardening in Ouagadougou, Burkina Faso. PhD Thesis, University of Basel, Basel p. 428.

Hayat K, Ashfaq M, Ashfaq U, Ahmad Saleem M (2010). Determination of pesticide residues in blood samples of villagers involved in pesticide application at District Vehari (Punjab), Pakistan. Afr. J. Environ. Sci. Technol. 4(10):666-684.

Jondreville C, Revy P, Jaffrezic A, Dourmad J (2002). Copper in pig feed: essential trace element, growth factor and potential risk to human and environment. INRA Prod. Anim. 15:247-265.

Kabata-Pendias A, Pendias $H$ (2001). Trace elements in soils and plants. CRC Press, Boca Raton p. 413.

Kamdem SM, Fofiri NEJ (2008). Market gardening in Ngaoundere: production constraints and health risks. In Farming and urban development in Sub-Saharan Africa: environmental and health issues, Harmattan, Paris, France pp. 161-168.

Kanda M (2003). Plant diversity and pesticides use in market gardens of Lomé. MSc. Thesis, Faculty of Agric Science, University of AbomeyCalavi (Benin) p. 71

Kanda M (2011). Market gardening in Togo: systemic and environmental analysis. PhD thesis, University of Lomé, Togo p. 179.

Keith LH (1990). Environmental sampling: a summary. Environ. Sci. Technol. 24:610-617.

Kishimba MA, Henry L, Mwevura $\mathrm{H}$, Mmochi AJ, Mihale M, Hellar $\mathrm{H}$ (2004). The status of pesticide pollution in Tanzania. Talanta 64:4853.

Koc M, Macrae R, Mougeot JAL, Welsh J (2000). Arming cities against 
hunger: sustainable urban food systems. CRDI, Ottawa p. 243.

Kouakou KJ, Bekro YA, Sika AE, Baize D, Dogbo DO, Bounakhla M, Zahry F, Macaigne P (2008). Diagnosis of trace metals contamination in spinach (Spinacia oleracea) grown on gardens soils amended with poultry manure in Abidjan (Côte d'Ivoiret). Eur. J. Sci. Res. 21(3):471487.

Levasseur P (2002). Detailed chemical composition of food and pig manure. Techni 25:19-25.

Manirakiza P, Akinbamijo O, Covaci A, Pitonzo R, Schepens P (2003). Assessment of organochlorine pesticide residues in West African City Farms: Banjul and Dakar case study. Arch. Environ. Contam. Toxicol. 44:171-179.

Marcato C (2007). Origin, fate and impact of copper and zinc from swine manure. Role of anaerobic digestion. PhD Thesis, INP Toulouse p. 199.

Mawussi G (2008). Environmental balance on the use of organochlorine pesticides in cotton, coffee and cocoa culture in Togo and alternatives research through insecticidal effects of plant extracts against Hypothenemus hampei Ferrari. PhD Thesis, University of Toulouse p. 154.

Midmore DJ, Jansen HGP (2003). Supplying vegetables to Asian cities: Is there a case for periurban production. Food Pol. 28:13-27.

Mougeot LJA (2005). Agropolis: The Social, political and environmental dimensions of urban agriculture. IDRC, Earthscan, London p. 286.

Mwevura H, Othman OC, Mhehe GL (2002). Organochlorine pesticides residues in waters from the coastal area of Dar-es-Salaam and their effect on aquatic biota. Tanzania J. Sci. 28(2):117-130.

Niang S (1996). Use of domestic wastewater in periurban agriculture in Dakar (Senegal). Cahiers Sécheresses 3:217-223.

Nicholson F, Smith S, Alloway B, Carlton-Smith C, Chambers B (2003). An inventory of heavy metals inputs to agricultural soils in England and Wales. Sci. Total Environ. 311:219.

Ntow WJ (2001). Organochlorine pesticides in water, sediment, crops, and human fluids in a farming community in Ghana. Arch. Environ. Contam. Toxicol. 40:557-563.

Ntow WJ (2005). Pesticide residues in Volta Lake, Ghana. Lakes and Reservoirs. Res. Manag. 10:243-248.

Otani T, Seike N, Sakata Y (2007). Differential uptake of dieldrin and endrinfrom soil by several plant families and Cucurbita genera. Soil Sci. Plant. Nutr. 53:86-94.

Pélissier P (2000). Opening address. In Rural-urban interactions. University of Dakar Cheikh Anta Diop pp.126-134.

Perkin E (1999). The Simultaneous Determination of $\mathrm{Pb}, \mathrm{Cd}, \mathrm{Cr}, \mathrm{Cu}$ and $\mathrm{Ni}$ in Potable and Surface Waters by GFAAS According to International Regulations, Atomic Spectroscopy 20:4.

Public Health Council of France (1996). Lead, cadmium and mercury in food: assessment and risk management. Lavoisier TEC \& DOC, France p. 237.
Ramade F (1992). Specific ecotoxicology. Masson Ed., Paris, 300 p.

Richard Y, Giroux I (2004). Impact of agriculture on benthic communities and fish in the Saint-Georges creek (Quebec, Canada). Ministry of Environment, Québec, Québec, Envirodoq, Coll. QE/148 p. 28.

Saliot A, Bouloubassi I, Lipiatou E (1992). Strategies of sampling and analysis applied to the study of organic pollutants in coastal water. Hydroecol. Appl. 4:9-12.

Savadogo PW, Traoré O, Topan M, Tapsoba KH, Sedogo PM, BonziCoulibaly L-Y (2006). Variation in pesticide residue concentrations in soils of the cotton zone of Burkina Faso. J. Afr. Sci. Environ. 1:29-39.

Schilter C (1991a). Urban agriculture in Lomé. Agronomic and socioeconomic approaches. IUED, Karthala, Paris p. 334

Schilter C (1991b). Urban agriculture: an activity that creates jobs in a subsistence economy (The case of Lomé). Cah. Sci. Hum. 27(72):159-168.

Shtangeeva $Y$ (2005). Trace and ultratrace elements in plants and soil. WIT Press. p. 348

SOGREAH (2007). Contaminants flow balance in agricultural soils in France. Quantitative assessment of contamination by trace elements and trace organic compounds and quantitative application for trace elements. ADEME p. 283.

Talaki K (2002). Pests' management in market gardens of Lomé. MSc. Thesis, Swedish University of Agricultural Sciences (SLU). p. 27.

Tarras-Wahlberg NH, Flachier A, Lane SN, Sangfors D (2001). Environmental impacts and metal exposure of aquatic ecosystems in rivers contaminated by smoll scale gold mining: The Puyango River basin, southern Ecuador. Sci. Total Environ. 278:239-261.

Traoré SK, Mamadou K, Dembéle A, Lafrance P, Mazellier P, Houénou P (2006). Contamination of groundwater by pesticides in Cote d'Ivoire agricultural regions (Center, South and South-West). J. Afr. Sci. Environ. 1:1-9.

Tremel-Schaub A, Feix I (2005). Soils contamination. Transfer from soils to plants. EDP Sciences, ADEME p. 416.

World Health Organisation (WHO) (1993). Guidelines for drinking water quality. $2^{\text {nd }}$ Recommendations, WHO, Genève.

World Health Organisation (WHO) (1998). Guidelines for Drinking water quality, $2^{\text {nd }}$ Edition, Addendum to vol. 2 . Health Criteria and other supporting information. World Health Organization, Geneva pp. $201-$ 208. 